\title{
First Aeromycological Profile of the Mandangad tahsil, Maharashtra, India
}

\author{
V.D. Chavan \\ Loknete Gopinathji Munde Arts, Commerece and Science College Mandangad, District Ratnagiri, Maharashtra, India \\ Corresponding authorEmail: vinod80kumar@gmail.com \\ (Submitted on January 25, 2020; Accepted on May 15, 2020)
}

\begin{abstract}
Aim of this survey is to present the first aeromycological report of Mandangad tahsil, Ratnagiri, Maharashtra, India. In all 22 species of 16 genera from the 14 different localities of Mandangad tahsil were isolated successfully. From amongst the isolated fungi the species of Aspergillus, Rhizopus and Mucor were found to be the most dominating microbial components of the aeromycoflora whereas Alternaria solani, Emmonsia pasteuriana, Curvularia lunata, Candida albicans, Humicola grisea, Penicillium spp., Rhizoctonia solani and Satchybotrys chartarum were least abundant in comparison. Some of these including Sclerotium rolfsii, Fusarium oxysporum, Fusarium solani, Fusarium dimerum, Cladosporium cladosporioides, Cladosporium herbarum and Cladosporium chartarum showed general abundance. Hence first aeromycological profile of Mandangad tahsil apprise us about the fungal aeromycoflora affecting local medicinal and timber plants, human population, fruits, food products, clothes, furniture, leather products and dairy products, etc.

Keywords: Fungal diversity, airborne, Aspergillus, Alternaria, Mucor spp., aeromycology
\end{abstract}

\section{INTRODUCTION}

Mandangad tahsil is a hilly coastal biodiversity rich and socio-economically backward zone of Ratnagiri district of Maharashtra state, India. Symptoms of fungal infections are easily noticeable on plant parts as well as among the human population of this region. In Mandangad heavy rainfall during monsoon season and nearby Arabian Sea favours high relative humidity which plays a pivotal role in fungal infestations of the plants and plant products including human and animal population in the nearby surroundings in Mandangad. Hence, the study on fungal pathogens and looking for a solution to tackle the menace is of great importance and a sort of challenge before the mycologists and plant pathologists.

Therefore, in view of the public interest involved the main aim of this study was to construct the first aeromycological profile by analyzing the diversity and frequency of the fungal pathogens in the air of Mandangad tahsil.

\section{MATERIALS AND METHODS}

Air sampling and fungal culture: Fungal samples from the 14 different localities of Mandangad tahsil were collected during June 2017 to February 2018. For this purpose settle plate method containing potato dextrose agar medium was used. The media containing plates were exposed to air for $1 \mathrm{hr}$. No sampling was undertaken during summer season because of less occurrence of fungal infestation due to the prevalence of drier climate. Four Plates per locality were used for sampling which were subsequently incubated at $20-28^{\circ} \mathrm{C}$ for 2-3 weeks and examined on daily basis for visible fungal growth. Purified fungal colonies were subcultured and subsequently identified to the generic level based on morphological features by consulting standard literature.

Identification of Plant fungal pathogens: Slides were prepared by using lacto phenol + cotton blue as a mounting medium and observed under the microscope (675X magnification). Fungi were identified using the available literature (Raper and Thom, 1984; Raper and Fennell, 1965; Ellis, 1971; Subramanian, 1960; Booth, 1977; Carmichael et. al., 1980; Waheganokar, 1984; Barnett and Hunter, 1998;
Gilman, 1957; Nagmani et. al., 2006; Mukadum et. al., 2006; Salunkhe and Wahegaonkar, 2016).

Statistical Analysis for species diversity: The diversity of fungal species was studied in terms of species richness and relative abundance of the species.

i) Species richness (S): (Harrison et. al, .2004).

It represents the total number of different species in a particular area.

\section{ii) Relative Dominance}

It was measured by calculating the Berger-Parker dominance index.

$\mathrm{d}=\mathrm{n} / \mathrm{N}$

Where, $\mathrm{n}=$ number of individuals in a species

$\mathrm{N}=\mathrm{S}=$ Total number of individuals

\section{RESULTS}

In all 42 samples of fungi ( 3 samples from each site) were collected from 14 different sites of Mandangad tahsil. After seven days of incubation each fungal colony was examined under the microscope at higher magnification. Examination of the fungal cultures resulted in the documentation of sixteen fungal genera with 22 species. Diversity of fungi in the Mandangad tahsil was assessed by studying various factors like species richness, relative dominance and diversity of fungal species. It is normally assumed that more the number of species present in a locality 'richer' is the locality. Highest numbers of isolates ( 15 Genera out of 16) were recorded from the Palavni site. Kuduk and Adkhal site was quite poor in this regard. From Kuduk six taxa, namely Aspergillus niger, Mucor, Rhizopus spp., Aspergillus flavus, Papulospora irregulans, Rhizoctonia solani and from Adkhal only five taxa, namely Aspergillus niger, Mucor, Rhizopus spp., Penicillium spp. and Aspergillus flavus were documented in comparison (Fig. 1 \& Table 1).

The Berger-Parker index for relative dominance was calculated at the generic level (Berger and Parker, 1970). The genera Aspergillus, Rhizopus and Mucor appeared as the most 


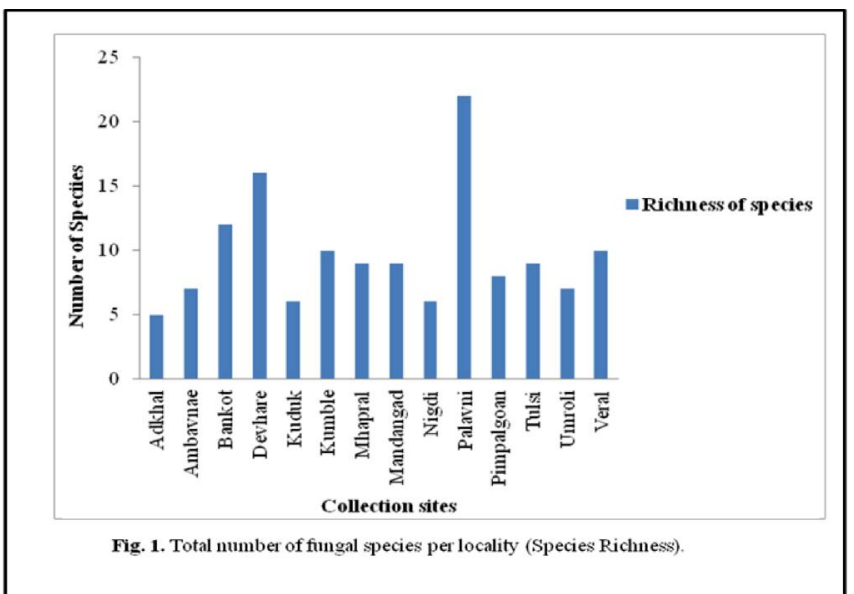

Table 1. Number of Fungal Species per Locality

\begin{tabular}{|c|c|c|}
\hline $\begin{array}{l}\text { Sr. } \\
\text { No. }\end{array}$ & $\begin{array}{c}\text { Collection } \\
\text { Site }\end{array}$ & Name of the Fungal species \\
\hline 1 & Adkhal & $\begin{array}{l}\text { Aspergillus niger, Mucor spp., Rhizopus spp., Aspergillus flavus, } \\
\text { Penicillium }\end{array}$ \\
\hline 2 & Ambavnae & $\begin{array}{l}\text { Aspergillus niger, Cladosporium cladiosporioides, Candida } \\
\text { albicans, Mucor } \text { spp., Rhizopus spp., Cladosporium oxysporum, } \\
\text { Papulospora irregulans, }\end{array}$ \\
\hline 3 & Bankot & $\begin{array}{l}\text { Aspergillus niger, Aureobasidium pullulans, Cladosporium } \\
\text { cladiosporioides, Mucor spp., Rhizopus spp., Stachybotrys } \\
\text { chartarum, Cladosporium harbarum, Cladosporium oxysporum, } \\
\text { Aspergillus flavus, Papulospora irregulans, Rhizoctonia solani, } \\
\text { Sclerotium rolfsii, }\end{array}$ \\
\hline 4 & Devhare & $\begin{array}{l}\text { Alternaria alternata, Aspergillus niger, Aureobasidium } \\
\text { pullulans, Cladosporium cladiosporioides, Fusarium oxysporum, } \\
\text { Fusarium solani, Fusarium dimerum, Mucor spp., Rhizopus } \\
\text { spp., Cladosporium harbarum, Cladosporium oxysporum, } \\
\text { Humicola grisea, Aspergillus flavus, Papulospora irregulans, } \\
\text { Rhizoctonia solani, Sclerotium rolfsii }\end{array}$ \\
\hline 5 & Kuduk & $\begin{array}{l}\text { Aspergillus niger, Mu cor } \text { spp., Rhizopus spp., Aspergillus flavus, } \\
\text { Papulospora irregulans, Rhizoctonia solani }\end{array}$ \\
\hline 6 & Kumble & $\begin{array}{l}\text { Aspergillus niger, Cladosporium cladiosporioides, Fusarium } \\
\text { oxysporum, Mucor spp., Rhizopus spp., Penicillium spp., } \\
\text { Stachybotrys chartarum, Humicola grisea, A spergillus flavus, } \\
\text { Papulospora irregulans }\end{array}$ \\
\hline 7 & Mhapral & $\begin{array}{l}\text { Alternaria alternata, Aspergillus niger, Emmonsia pasteuriana, } \\
\text { Fusarium oxysporum, Fusarium solani, Fusarium dimerum, } \\
\text { Mucor spp., Rhizopus spp., Aspergillus flavus }\end{array}$ \\
\hline 8 & Mandangad & $\begin{array}{l}\text { Aspergillus niger, Cladosporium cladiosporioides, Mucor spp., } \\
\text { Rhizopus spp., Stachybotrys chartarum, Cladosporium } \\
\text { harbarum, Cladosporium oxysporum, Aspergillus flavus, } \\
\text { Sclerotium rolfsii }\end{array}$ \\
\hline 9 & Nigdi & $\begin{array}{l}\text { Aspergillus niger, Aureobasidium pullulans Fusarium } \\
\text { oxysporum, Mucor } \text { spp., Rhizopus Sclerotium rolfsii }\end{array}$ \\
\hline 10 & Palavni & $\begin{array}{l}\text { Alternaria alternata, Aspergillus niger, Aureobasidium } \\
\text { pullulans, Cladosporium cladiosporioides, Candida albicans, } \\
\text { Emmonsia pasteuriana, Fusarium oxysporum, Fusarium solani, } \\
\text { Fusarium dimerum, Mucor spp., Rhizopus spp., Penicillium } \\
\text { spp., Stachybotrys chartarum, Cladosporium harbarum, } \\
\text { Cladosporium oxysporum, Humicola grisea, Aspergillus flavus, } \\
\text { Curvularia lunata, Papulospora irregulans, Rhizoctonia solani, } \\
\text { Sclerotium rolfsii, Alternaria solani }\end{array}$ \\
\hline 11 & Pimpalgoan & $\begin{array}{l}\text { Alternaria alternata, Aspergillus niger, Cladosporium } \\
\text { cladiosporioides, Candida albicans, Rhizopus spp., } \\
\text { Cladosporium harbarum, Cladosporium oxysporum, } \\
\text { Papulospora irregulans }\end{array}$ \\
\hline 12 & Tulsi & $\begin{array}{l}\text { Aspergillus niger, Fusarium oxysporum, Fusarium solani, } \\
\text { Fusarium dimerum, Mucor spp., Rhizopus spp., Penicillium } \\
\text { spp., Cladosporium harbarum, Humicola grisea }\end{array}$ \\
\hline 13 & Umroli & $\begin{array}{l}\text { Alternaria alternata, Aspergillus niger, Aureobasidium } \\
\text { pullulans, Mucor spp., Rhizopus spp., Aspergillus flavus, } \\
\text { Curvularia lunata, Papulospora irregulans }\end{array}$ \\
\hline 14 & Veral & $\begin{array}{l}\text { Aspergillus niger, Cladosporium cladiosporioides, Fusarium } \\
\text { oxysporum, Fusarium solani, Fusarium dimerum, Mucor spp., } \\
\text { Rhizopus spp., Cladosporium harbarum, Cladosporium } \\
\text { oxysporum, Papulospora irregulans }\end{array}$ \\
\hline
\end{tabular}

dominant genera in all localities whereas Alternaria solani, Emmonsia pasteuriana, Curvularia lunata, Candida albicans, Humicola grisea, Penicillium spp., Rhizoctonia solani and Satchybotrys chartarum were least abundant in comparison. Whereas Sclerotium rolfsii, Fusarium oxysporum, Fusarium solani, Fusarium dimerum,

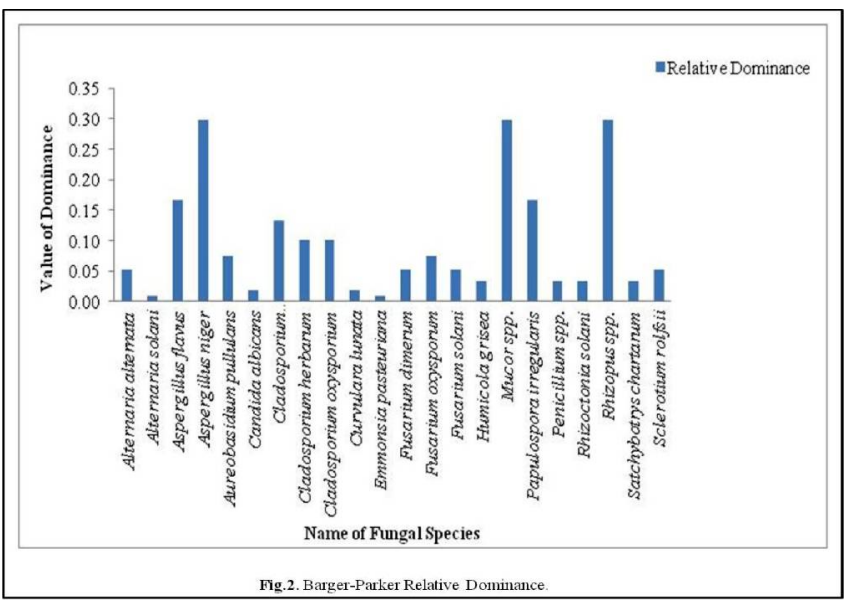

Table 2. Frequency and Relative Dominance of Species.

\begin{tabular}{|c|l|c|c|c|}
\hline $\begin{array}{c}\text { Sr. } \\
\text { No. }\end{array}$ & \multicolumn{1}{|c|}{ Name of the Species } & $\begin{array}{c}\text { \% Frequency } \\
\text { of per } \\
\text { Species }\end{array}$ & $\begin{array}{c}\text { Berger- } \\
\text { Parker } \\
\text { Dominance } \\
\text { Index 'd' }\end{array}$ & $\begin{array}{c}\text { Relative } \\
\text { Dominance }\end{array}$ \\
\hline 1 & Alternaria alternata & 35.71 & 0.05 & $\mathrm{G}$ \\
\hline 2 & Alternaria solani & 14.29 & 0.01 & $\mathrm{R}$ \\
\hline 3 & Aspergillus flavus & 64.29 & 0.17 & $\mathrm{D}$ \\
\hline 4 & Aspergillus niger & $\mathbf{1 0 0 . 0 0}$ & 0.30 & $\mathrm{D}$ \\
\hline 5 & Aureobasidium pullulans & 42.86 & 0.07 & $\mathrm{G}$ \\
\hline 6 & Candida albicans & 21.43 & 0.02 & $\mathrm{R}$ \\
\hline 7 & Cladosporium & 57.14 & 0.13 & $\mathrm{D}$ \\
\hline 8 & Cladosporioides & 50.00 & 0.10 & $\mathrm{D}$ \\
\hline 9 & Cladosporium herbarum & 50.00 & 0.10 & $\mathrm{D}$ \\
\hline 10 & Curvulara lunata & 21.43 & 0.02 & $\mathrm{R}$ \\
\hline 11 & Emmonsia pasteuriana & 14.29 & 0.01 & $\mathrm{R}$ \\
\hline 12 & Fusarium dimerum & 35.71 & 0.05 & $\mathrm{G}$ \\
\hline 13 & Fusarium oxysporum & 42.86 & 0.07 & $\mathrm{G}$ \\
\hline 14 & Fusarium solani & 35.71 & 0.05 & $\mathrm{G}$ \\
\hline 15 & Humicola grisea & 28.57 & 0.03 & $\mathrm{R}$ \\
\hline 16 & Mucor spp. & $\mathbf{1 0 0 . 0 0}$ & 0.30 & $\mathrm{D}$ \\
\hline 17 & Papulospora irregularis & 64.29 & 0.17 & $\mathrm{D}$ \\
\hline 18 & Penicillium spp. & 28.57 & 0.03 & $\mathrm{R}$ \\
\hline 19 & Rhizoctonia solani & 28.57 & 0.03 & $\mathrm{R}$ \\
\hline 20 & Rhizopus spp. & $\mathbf{1 0 0 . 0 0}$ & 0.30 & $\mathrm{D}$ \\
\hline 21 & Satchybotrys chartarum & 28.57 & 0.03 & $\mathrm{R}$ \\
\hline 22 & Sclerotium rolfsii & 35.71 & 0.05 & $\mathrm{G}$ \\
\hline
\end{tabular}

Cladosporium cladosporioides, Cladosporium herbarum, Cladosporium chartarum showed general abundance in comparison (Fig. 2 \& Table 2). Out of 16 fungal genera documented 12 were members of Phylum Ascomycota.

\section{DISCUSSION}

During the present survey a number of airborne fungal pathogens were recorded in the air of Mandangad tahsil. In all 22 species belonging to 16 genera were found to be from 14 different localities of Mandangad tahsil which were isolated successfully. Most of the documented fungal taxa were either plant pathogens or some of them were allergenic to human population (Thirumala and Nathu, 2013). This observation is in conformity with earlier such report by Pavan and Manjunath (2014) based upon their studies undertaken at Hesaraghatta village, Bangalore. As has been documented presently, the presence of Aspergillus in the air has been reported as the major risk factor for invasive aspergillosis by Campbell (1994). In another study, Dimitrov et. al. 1990 reported the presence of high concentration of potentially allergenic and toxigenic air mycoflora (Alternaria, Aspergillus, Cladosporium, Fusarium and Penicillium) in 
and around cotton and soybean mills. Similar observation was made during the present survey. Throughout this survey the species of Aspergillus, Mucor and Rhizopus were quite common in all selected localities of Mandangad tahsil, indicating their dominance and ability to adapt easily to different environments and cause various types of allergic reactions in the dwelling population. In one of the recent study by Nielsen (2003) it was reported that Aspergillus, Penicillium, Fusarium, Alternaria and Trichoderma are the most frequently found fungal genera in the environment which are the main mycotoxin producers that can cause mycotoxicosis. It is a well known fact that mycotoxicosis is one of the major causes responsible for deterioration of liver and kidney functions if ingested by humans through infected food items (Marasas et. al., 2011). Genus Cladosporium documented during the present study is also reported to be the main component of airborne mycobiota in various regions of the world.

Extensive survey of plant pathogenic fungi in different forest ecosystems in the Western Ghats revealed the extensive occurrence of plant pathogenic fungi harboring the plants and causing different diseases of varying intensities (Mohanan, 2005). Fungal genera Alternaria and Cladosporium are reported to cause diseases of large variety of plants (Moss, 2008). Roy and Chourasia (1990) isolated Aspergillus flavus, A. niger, A. ocharaceus, Penicillium citrinum, Penicillium spp., Fusarium moniliforme, Fusarium spp., from the roots of Asparagus racemosus. All such reports are indicative of the occurrence of such plant pathogenic and allergy causing fungi as has been observed in the air of Mandangad, which are responsible for various plants and human ailments in the region.

In one of the latest study, Udoh et. al. (2015) reported the role of Mucor, Rhizopus, Candida albicans, Aspergillus, Penicillum and Fusarium in the deterioration of the various fruits, vegetables and also in causing allergenic reactions in human population. In addition to their role in the deterioration of fruits and vegetables, fungi are also known to cause deterioration of milk, cheese, corn, peanuts, cotton, nuts, almonds and herbs, etc. (Mailafia et. al., 2017). During the present study also species of Mucor, Rhizopus Aspergillus, Cladosporium, Penicillum, Fusarium and Candida albicans, in Mandangad tahsil have also been documented to play a major role in the deterioration of various vegetables, fruits and dairy products at market places and at home.

\section{CONCLUSION}

It can be concluded that various plants as well as local population of Mandangad tahsil are under the cloud of various infectious fungi present in the surrounding environment. The current survey on the aeromycological profile of Mandangad tahsil is of utmost relevance to the foresters, nursery coordinators as well as local residents which helps to apprise them about the specific infective fungal pathogens in their immediate vicinity against which advance prophylactic measures can be initiated.

\section{ACKNOWLEDGEMENT}

Principal Investigator gratefully acknowledges the financial assistance received from University of Mumbai. Author is also thankful to Dr. Sopan Salunkhe for his help in identification of the fungal taxa during this study.

\section{REFERENCES}

Barnett, H. and Hunter, B. 1998. Illustrated Genera of Imperfect Fungi. APS press, Minnesota, USA. 218pp.

Berger, W. and Parker F. 1970. Diversity of Planktonic Foraminifera in deep-sea sediments. Science 168: 1345-1347.

Booth C. 1977. Fusarium . CMI, Kew, Surrey, London.

Campbell, C. 1994. Forms of aspergillosis. In: The Genus Aspergillus (Eds.: Powell, K. A., Renwick, A. and Pederdy,J. F.). New York: Plenum, pp. 313-320.

Carmichael, J., Kendrick, W., Conners, I. and Sigter, L. 1980. Genera of Hyphomycetes. The University Alberta, Edmonton, Alberta, Canada. pp. 386.

Dimitrov, M., Ivanova-Dzhubrilova, S., Nikolcheva, M. and Drenska, E. 1990. The mycotoxicological and dust contamination of the air in plants for the preliminary processing of cotton and hemp. Probl. Gig. 15: 121127.

Ellis, M. B 1971. Dematiaceous Hyphomycetes. CAB International, Published by commonwealth mycological institute, England.Pp.608.

Gilman, J. C. 1957. A Manual of soil fungi. Ames, Iowa. Pp. 450.

Harrison, I., Laverty, M. and Sterling, E. 2004. Species Diversity, Connexions module: m12174, 05.08 .2011 , Ava i 1 a ble from http://cnx.org/content/m12174/latest/

Mailafia, S., Okoh, G., Olabode, H. and Osanupin, R. 2017. Isolation and identification of fungi associated with spoilt fruits vended in Gwagwalada market, Abuja, Nigeria, Veterinary World 10 (4): 393-397.

Marasas, W., Miller, W., Riley, R., and Viscontini, A. 2011. Fusmonisins occurrence, toxicology, metabolism and risk assessment," In: Fusarium : Paul E. Nelson, Memorial Symposium (Eds.: Summerell, B.A., Leslie, J.F., Backhouse, D. and Bryden, W.L.), pp. 332-359, APS Press, Saint Paul, Minn, USA.

Mohanan, C. 2005. Diseases of rattan in nurseries, plantations and natural stands. Journal of Bamboo and Rattan 3:235-261.

Moss, M. 2008. Fungi, quality and safety issues in fresh fruits and vegetables. Journal of Applied Microbiology 104: 1239-1243.

Mukadam, D., Chavan, A., Patil, M. and Patil, A. 2006. The Illustration of Fungi. Saraswati printing press, Aurangabad, India. Pp. 254.

Nagmani, A., Knwar, I. and Manoharachary, C. 2006. Handbook of Soilfungi. I.K. Innternational, pp 477. 
Nielsen, K. 2003. Mycotoxin production by indoor molds. Fungal Genetics and Biology. 39 (2): 103-117.

Pavan, R. and Manjunath, K. 2014. Qualitative Analysis of Indoor and Outdoor Airborne Fungi in Cowshed. Journal of Mycology 2014:1-8.

Raper, K.B. and Fennell, D.I. 1965. The Genus Aspergillus, The Williams and Wilkins company Baltimore. Pp. 686.

Raper, K. and Thom, C. 1984. Manual of the Penicillia. Indian reprint, International books and Periodicals Supply service, Delhi. Pp. 875.

Roy, A. and Chourasia, H. 1990. Mycoflora, mycotoxin producibility and mycotoxins in traditional herbal drugs from India. J. Gen. Appl. Microbiol. 36: 295302.

Salunkhe, S. and Wahegaonkar, N. 2016. Studies on hypomycetous fungi from soils of Aurangabad. Thesis retrieved from, Shodhaganga.inflibnet.ac.in.

Subramanian, C. 1960. Subsrate relationship in Soil Fungi. Mem. Indian Bot. Soc. 3:108-119.

Thirumala, S. and Nathu, M. 2013. Study of Fungal Spores Diversity, in Malebenur Region of Karnataka, India. Int.J.Curr.Microbiol.App.Sci. 2 (3): 44-48.

Udoh, I., Eleazar, C., Ogeneh, B and Ohanu, M. 2015. Studies on Fungi Responsible for the Spoliage/Deterioration of Some Edible Fruits and Vegetables. Advances in Micro. 5: 285-290.

Waheganokar, N. 1984. The study of the mycoflora of the industrial wastes from some paper and pulp factories in Maharashtra state. Ph.D. Thesis submitted to MACS / ARI, Pune 